\title{
Meycauayan, an industrial city in Bulacan, Philippines: Heavy metal pollution in soil and surface sediments and their relationship to environmental indicators
}

\author{
Reymar R. Diwa ${ }^{1}$, Custer C. Deocaris ${ }^{1,4,5}$, Aileen H. Orbecido², Arnel B. Beltran ${ }^{2}$, Edgar A. Vallar ${ }^{3}$, \\ Maria Cecilia D. Galvez ${ }^{3}$, and Lawrence P. Belo ${ }^{2,5, *}$ \\ ${ }^{1}$ Philippine Nuclear Research Institute, Department of Science \& Technology, Diliman, Quezon City 1101, Philippines \\ ${ }^{2}$ Chemical Engineering Department, De La Salle University, Manila 1004, Philippines \\ ${ }^{3}$ Physics Department, De La Salle University, Manila 1004, Philippines \\ ${ }^{4}$ Technological Institute of the Philippines, 938 Aurora Blvd., Cubao, Quezon City 1109, Philippines \\ ${ }^{5}$ BANToxics Inc., Barangay Central, Quezon City, 1100 Philippines
}

\author{
Author Information \\ * To whom correspondence should be addressed to. \\ Corresponding author: \\ Dr. Lawrene P. Belo \\ Address: De La Salle University \\ 2401 Taft Avenue, Manila 0922 Philippines \\ Phone: +63(2) 85360257 ; Mobile: +63(917) 8362356 \\ E-mail: lawrence.belo@dlsu.edu.ph
}

\section{HIGHLIGHTS}

- Several industries drive heavy metal pollution in surface sediments in Meycauayan, Bulacan, Philippines.

- Cr concentration in Meycauayan, the "leather capital of the Philippines," is more than three times the world average in rivers and lakes due to the rapid proliferation of small-scale leather tanneries since the 1970s.

- $\mathrm{Cr}$ and $\mathrm{Pb}$ contributed to the highest incidences of ecological toxicity at $91.7 \%$ and $53.6 \%$, respectively.

- Stronger environmental policy towards betting regulation of both the leather tannery and lead acid-battery recycling industries in Meycauayan are needed considering cultural and environmental risk factors.

\begin{abstract}
The City of Meycauayan is an industrial powerhouse in the Philippines. It is considered as one of the most polluted cities in the developing world on the account of industrial discharges of toxic materials to the environment. This work investigated the sources of the heavy metal pollution in Meycauayan by analyzing soil and sediment samples for heavy metals (Cr, Hg, $\mathrm{Ni}$, and Pb) together with selected environmental indicators (TN, TOM, and TP) located along the Meycauayan River. Hierarchical cluster analysis (HCA), principal components analysis (PCA), and Pearson correlation analysis (CA) were used to identify the sources of the metals. Our results show delineated locations of severe levels of heavy metal pollution downstream of the river because of the concentration of industrial activities. Cr contributed more to heavy metal pollution than any other heavy metals analyzed due to proliferation of tanneries discharging untreated wastewaters to the river. Significant input of Pb and $\mathrm{Hg}$ from $\mathrm{Pb}$ acid battery recycling and gold smelting industries were also found. The risk assessments indicate severe levels of heavy metal pollution in locations where industrial activities are concentrated. The mean $\mathrm{Cr}, \mathrm{Pb}, \mathrm{Ni}$, and $\mathrm{Hg}$ in the sampling locations have mean incidences of toxicity of $91.7 \%, 53.6 \%, 27.7 \%$, and 70.0 \%, respectively. Our study shows the serious need to address heavy metal pollution in Meycauayan aside from the ongoing cleanup of solid wastes as part of rehabilitation efforts by the local government.
\end{abstract}

Keywords: heavy metals, sediments, MMORS, Meycauayan River, soil pollution, multivariate analysis, Sediment Quality Guidelines, Single Pollution Index 


\section{INTRODUCTION}

Soil plays a vital role in an ecosystem by supporting the biogeochemical cycles (i.e. hydrologic, carbon, nutrients) as well as by providing food and raw materials [1]. Unfortunately, degradation and contamination of soils are accelerated due to anthropogenic activities. For developing countries like the Philippines, rapid urbanization and industrialization, expanding population, intensified agriculture, and irresponsible disposal of wastes add to the degrading soil quality [2]. Soil pollution by heavy metals is one of the most common and persistent problems worldwide [1,3,4]. Heavy metals are defined as elements with metallic properties and have atomic masses greater than $20(>20 \mathrm{amu})[2,5]$. The most common heavy metals are arsenic (As), cadmium $(\mathrm{Cd})$, cobalt $(\mathrm{Co})$, chromium $(\mathrm{Cr})$, copper $(\mathrm{Cu})$, iron $(\mathrm{Fe})$, mercury $(\mathrm{Hg})$, manganese $(\mathrm{Mn})$, nickel $(\mathrm{Ni})$, lead $(\mathrm{Pb})$, and zinc $(\mathrm{Zn})[2,3,6,7]$. These heavy metals could originate from a wide variety of sources which include airborne emissions, process solid wastes (e.g. fly ash, slags, ion exchange resins, spent catalysts, dumpsite waste), sludges, and spills [4].

Soils normally contain low background levels of heavy metals [8]. However, increasing heavy metal contamination levels on surface soils degrade soil quality and reduce crop yield and crop quality [3]. These heavy metals enter the food chain from polluted soil, water, and air which cause food and water contamination, thereby posing a threat to the health of humans, animals, and the ecosystem [2$4,7,9]$. Therefore, the need to identify the heavy metals and their sources, the distribution in the surface soils and sediments, and quantify the concentrations is of utmost importance.

The City of Meycauayan, one of the oldest towns in the province of Bulacan, is a pollution hotspot in the Philippines [10,11]. Its $32.10 \mathrm{~km}^{2}$ area concenters many pollutive industries, namely lead-acid battery recycling, jewelry making, gold-smelting, tanneries, open dumpsites, electroplating, including piggeries and poultry farms. To date, several of these industries generally do not have waste treatment facilities, and their effluents find their way to the surface water system. In 2007, the river system that transverses Meycauyan, the Marilao-Meycauayan-Obando River (MMOR), was cited as one of the "30 most polluted rivers in the world" by the Blacksmith Institute due to its huge discharge and accumulation for years of pollutants $[12,13]$. What contributes to the deteriorating air, water, and soil quality of Meycauayan is the rapid expansion of these industries coupled to the rapid growth of its urban population, especially the "informal settlers." These "informal settlers" are those families living in slums with no legal tenure over the land they occupy and densely inhabit private and public properties without access to adequate housing, sanitation, and clean water [14]. With the boom of unregulated precious metals and tanning industries in Bulacan in the past decade, heavy metal contaminations have gravely affected not just the river and its tributaries, but also the soil along the stretch of the river.

Previous studies have observed significant enrichment of heavy metals in the surface sediments, soil and water of the MMOR system [10,11,14]. With this, a pressing need to continuously conduct environmental monitoring and assessment work on the river quality (water, sediments, soil, and biodiversity) in the thrust to rehabilitate MMOR is imperative. The surface soils, which also serve as important sinks of pollution [3,15], will help understand the overall status of heavy metal pollution, its distribution, and associated risks for Meycauayan and its neighboring municipalities.

Heavy metal pollution and contamination are imminent in the Philippines due to its rapid industrialization. Further aggravating its heavy metal pollution are the numerous typhoons that visit the country [16]. At present, there are no existing standards for soil contamination in the Philippines. Understanding the overall status of the heavy metal pollution in Meycauayan could help initiate environmental and management policies that set standards for soil quality, cleanup protocols, and land use decisions in the country [8].

This study aims to establish baseline information and assessment on the physicochemical characteristics of soil along the stretch of the Meycauayan River to determine the current condition and assess the impacts of unregulated waste discharged on the quality of the river, its soils, and sediments. A total of seven (7) soil samples obtained along the stretch of the river were collected and analyzed. Results of soil testing were compared against international standards due to the absence of national and local soil pollution standards at present. Despite previous studies describing the heavy metal pollution in Meycauayan, the intensity of the pollution loading from specific tributaries is yet to be identified. To 
address this knowledge gap, this study identified the sources and assessed heavy metal contributions and areas of accumulation. To the best of the authors' knowledge, this is the first attempt to identify the provenance and source apportionment of heavy metal pollutants and their association with ecological risks and toxicity in Meycauayan. Moreover, the study outlines recommendations and unique perspectives on environmental policies and prioritization efforts that are not just focused on the risks of the hazardous materials but also considers the historical, cultural, and economic aspects of the region.

\section{METHODOLOGY}

\subsection{Study Area}

The City of Meycauayan is located $19 \mathrm{~km}$ north of Metro Manila and $22 \mathrm{~km}$ south of the City of Malolos, the capital of Bulacan province. It is the richest city in Bulacan due to its position as the province's economic, industrial, commercial, and financial epicenter. It is known for its jewelry, leather, and battery recycling industries. Meycauayan River is the primary waterway that traverses the city, with the main tributary having a course length of about $3.32 \mathrm{~km}$ [12]. It is classified as Class C River according to the Water Body Classification and Usage of Freshwater of the Department of Environment and Natural Resources (DENR) that designates it as fishery water for the propagation and growth of fish and other aquatic resources [17]. Meycauayan River is a fragment of a bigger river system in Bulacan called the Marilao-Meycauayan-Obando River System (MMORS). MMORS has been cited as one of the most polluted river systems in the world by Pure Earth, formerly, the Blacksmith Institute due to many years of unregulated discharge of domestic and toxic industrial wastes [11]. As a result, the Department of Environment and Natural Resources (DENR) designated MMORS as a 'Water Quality Management Area' to ensure that its water quality will meet the DENR's implementing rules and regulations, like the Clean Water Act of 2004 [18,19].

\subsection{Field Sampling}

The field sampling in 7 strategic sites in Meycauayan, as shown in Figure 1A, was conducted in May of 2016. Soils/surface sediment samples (0 to $0.2 \mathrm{~m}$ depth) were gathered from each sampling site. Sediment samples (SS1, SS2, SS3, SS4, and SS5) were collected along or near the riverbank, while soils samples (SS6 and SS7) were collected from agricultural and industrial sites. The sampling site selection was based on typical land-use patterns existing in Meycauayan, such as residential, agricultural, commercial, industrial, and landfill/dumpsite. The sampling locations consist mainly of residential areas with mixed land use such as reclaimed dumpsite (SS1), commercial and industrial (SS2, SS3, SS6, and SS7), and agricultural (SS4 and SS5).

\subsection{Laboratory Analysis}

Soil samples were stored in Ziploc plastic bags, kept at $-4^{\circ} \mathrm{C}$, and sent to a third-party environmental testing laboratory (CRL Environmental Corporation, Pampanga, Philippines). The testing laboratory, accredited by both the DENR and the Department of Health (DOH), is also ISO/IEC 17025:2005certified. For the heavy metal analysis, the soil samples were first acid digested then tested for chromium $(\mathrm{Cr})$, lead $(\mathrm{Pb})$, nickel $(\mathrm{Ni})$, and potassium $(\mathrm{K})$ using standard Flame Atomic Absorption Spectrometry (Flame AAS). Total Phosphorus (TP) was analyzed using the Vanadomolybdophosphoric Acid Colorimetric Method. Total Organic Matter (TOM) was analyzed determined using the standard Titrimetric Method. The cylinder tapping method was employed to assess soil/sediment density. Total Cyanide $(\mathrm{CN})$ was analyzed using Distillation/Ion-Selective Electrode Method; and lastly, Total Nitrogen was obtained by calculation $(\mathrm{TN}=$ Organic Nitrogen + Inorganic Nitrogen; Inorganic Nitrogen $=\mathrm{NH} 4-\mathrm{N}+\mathrm{NO} 3-\mathrm{N}+\mathrm{NO} 2-\mathrm{N}$ ).

\subsection{Statistical Analysis}

Multivariate analyses, such as the hierarchical cluster analysis (HCA), principal components analysis (PCA), and Pearson correlation analysis (CA), were performed using R statistical software (Version 4.0.4) to identify the sources of the heavy metals. HCA groups comparable parameters into clusters by calculating the distance between them and hierarchically arranging a sequence of partitions for these 
parameters [20]. PCA condenses the data's dimensionality to a new set of variables while minimizing the loss of information [21]. CA gives the degree of strength of linear correlation amongst two variables. These multivariate analyses are widely used in environmental pollution studies to identify pollution sources in air, water, and soil/sediments by grouping them according to similar sources. Bartlett's test was used to evaluate the validity of the CA and PCA. The distance between the elements for the clustering by HCA was derived using the Euclidean method. The algorithm used to link the clusters was the Single-link method. Correlation coefficients CA $>0.700$ were considered strong correlations for this study.

\subsection{Risk Assessment}

The heavy metals' ecological risks in the sediments were assessed using Sediment Quality Guidelines (SQG) and Single Pollution Index (PI). SQG provides a reliable basis for evaluating heavy metal pollution in sediments in freshwater domains that are influenced by several sources [22]. Meanwhile, PI is commonly used to determine which of the sampling locations and heavy metals pose the greatest risks for soil contamination [23].

The quotients of the concentrations of the individual heavy metals in the SQG were derived using the consensus-based Probable Effect Concentration (PEC) for freshwater ecosystems [22]. The mean of the quotients represents the sediment quality of the sampling locations. The incidence of toxicity associated with heavy metal contamination was assessed by direct comparison to heavy metal concentrations in the SQG. The PI was calculated by using the equation:

$$
\text { Single Pollution Index } P I_{i}=\frac{C_{n}}{B_{n}}
$$

, where $C_{n}$ is the heavy metal concentration of the sediment sample and $B_{n}$ is the background heavy metal concentration [24]. The mean of the PI contribution of the heavy metals represents the PI of the sampling locations. Restricted by the absence of headwaters where the background sample can be collected due to the very high level of urbanization in Meycauayan, this study used the Dutch Standards reference values for soil and sediments to calculate the PI [25]. The PI qualitative ratings are as follows: $\leq 1$ no pollution, $1-2$ low levels of pollution, $2-3$ moderate levels of pollution, $3-5$ strong levels of pollution, and $\geq 5$ very strong levels of pollution.

\section{RESULTS AND DISCUSSION}

\subsection{Concentration and source apportionment of heavy metals and other parameters}

The soil and sediment samples were collected from the following localities in Meycauayan: SS1 (Caingin), SS2 (Banga), SS3 (Calvario), SS4 (Camalig), SS5 (Langka), SS6 (Sto. Niño-Perez), and SS7 (Sterling). The concentration ranges of heavy metals and environmental indicators in soil and surface sediments at Meycauayan, particularly at selected sampling points along the river (Figure 1A), are presented in Tables 1 and 2. We found that SS3 (Calvario) contained the highest TP while SS2 (Banga) contained the highest TOM, TN, and $\mathrm{K}$. The sediment samples collected at these two sites also contained the highest heavy metal concentrations than the other sampling locations. More remarkable is the observation that their $\mathrm{Cr}, \mathrm{Pb}$, and $\mathrm{Hg}$ concentrations are 10.4-13.5, 1.42-1.25, and 1.3-2.1 times higher than the world average, respectively. The heavy metal concentrations of the sediments from SS1 (Caingin), SS4 (Camalig), SS5 (Langka), SS6 (Sto. Niño - Perez), and SS7 (Iba-Sterling) are significantly lower than the world average (Table 2). The mean concentrations of heavy metals from the soil and sediments along the Meycauayan river are significantly higher than those of other lakes and rivers in the Philippines. Specifically, $\mathrm{Cr}, \mathrm{Pb}, \mathrm{Ni}$, and $\mathrm{Hg}$ at Meycauayan are 2.4, 3.0, 0.36, and 1.1 times that of the mean concentrations in other freshwater bodies in the Philippines. However, this was not so with $\mathrm{Pb}, \mathrm{Ni}$, and $\mathrm{Hg}$ where the world average concentrations are greater than those in Meycauayan. 
Table 1. Concentration of heavy metals and other parameters in soils and surface sediments along the Meycauayan River.

\begin{tabular}{|c|c|c|c|c|c|c|c|}
\hline \multirow[b]{2}{*}{ Parameters } & \multicolumn{7}{|c|}{ Soil Sampling Location } \\
\hline & $\begin{array}{c}\text { SS1 } \\
\text { Caingin }\end{array}$ & $\begin{array}{c}\text { SS2 } \\
\text { Banga }\end{array}$ & $\begin{array}{c}\text { SS3 } \\
\text { Calvario }\end{array}$ & $\begin{array}{c}\text { SS4 } \\
\text { Camalig }\end{array}$ & $\begin{array}{c}\text { SS5 } \\
\text { Langka }\end{array}$ & $\begin{array}{c}\text { SS6 } \\
\text { Sto Nino- } \\
\text { Perez } \\
\end{array}$ & $\begin{array}{c}\text { SS7 } \\
\text { Sterling }\end{array}$ \\
\hline Density, $\mathrm{g} \mathrm{mL}^{-1}$ & 1.1224 & 0.6903 & 0.9026 & 0.7499 & 0.8138 & 1.0877 & 0.9246 \\
\hline $\mathrm{TP}, \mathrm{mg} \mathrm{kg}^{-1}$ & 209 & 481 & 1650 & 302 & 176 & 428 & 222 \\
\hline TOM, \% $\mathrm{w} \mathrm{w}^{-1}$ & 0.16 & 6.04 & 2.95 & 4.24 & 3.46 & 0.72 & 0.92 \\
\hline $\mathrm{TN}, \mathrm{mg} \mathrm{kg}^{-1}$ & 123 & 2400 & 1430 & 1500 & 160 & 122 & 123 \\
\hline $\mathrm{Cr}, \mathrm{mg} \mathrm{kg}^{-1}$ & 16 & 537 & 694 & 6.0 & 12 & 11 & 14 \\
\hline $\mathrm{Pb}, \mathrm{mg} \mathrm{kg}^{-1}$ & 9.2 & 195 & 172 & 23 & 45 & 30 & 31 \\
\hline $\mathrm{Ni}, \mathrm{mg} \mathrm{kg}^{-1}$ & 8.9 & 30 & 57 & 4.9 & 4.8 & 9.2 & 8.9 \\
\hline $\mathrm{Hg}, \mathrm{mg} \mathrm{kg}^{-1}$ & 0.3 & 1.4 & 0.9 & 0.2 & 0.4 & 0.2 & 0.2 \\
\hline $\mathrm{K}, \mathrm{mg} \mathrm{kg}^{-1}$ & 292 & 1160 & 549 & 537 & 197 & 415 & 562 \\
\hline
\end{tabular}

Table 2. The mean heavy metal concentration of soils and surface sediments in rivers and lakes in the Philippines, in the world, and in this study (mg $\mathrm{kg}^{-1}$ d.w.)

\begin{tabular}{rcccccc}
\hline \multirow{2}{*}{ Metal } & $\begin{array}{c}\text { Soils from rivers } \\
\text { and lakes in the } \\
\text { Philippines } \\
{[26-30]}\end{array}$ & \multicolumn{2}{c}{$\begin{array}{c}\text { Soils from rivers } \\
\text { and lakes in the } \\
\text { World } \\
{[31]}\end{array}$} & $\begin{array}{c}\text { Meycauayan River } \\
\text { (this study) }\end{array}$ \\
\cline { 2 - 7 } & Mean & Range & Mean & Range & Mean & Range \\
\hline $\mathrm{Cr}$ & 77.23 & $0.6-252$ & 51.51 & $0-234.6$ & 184.29 & $6-694$ \\
$\mathrm{~Pb}$ & 24.0 & $3.39-64.9$ & 137.3 & $0-5778.1$ & 72.17 & $9.2-195$ \\
$\mathrm{Ni}$ & 49.39 & $6.2-98.07$ & 127.59 & $1.2-7206$ & 17.67 & $4.9-57$ \\
$\mathrm{Hg}$ & 0.47 & $0.25-0.61$ & 0.68 & $0.052-7.6$ & 0.51 & $0.2-1.4$ \\
\hline
\end{tabular}

Multivariate analyses, such as HCA, PCA, and CA were used to identify the possible sources of heavy metals in the sediments and interpret these pollutants' spatial variations [32]. We identified two distinct clusters based on the sampling sites: Cluster 1 (SS4, SS5, SS1, SS6, and SS7) and Cluster 2 (SS2 and SS3). Notably, Cluster 1 is related solely to agricultural systems and human-animal wastes while Cluster 2 is associated with industrial wastes but somewhat also mixed with agricultural systems and humananimal wastes (Figure 1B). The cluster analysis of the sampling locations further differentiated the commercial and industrial locations such that SS2 and SS3 formed a cluster of their own. Based on the characteristics of the businesses in Meycauayan, these are locations where unregulated small-scale establishments of jewelry making, battery recycling, and tanneries are concentrated. The other two commercial and industrial locations, such as SS6 and SS7, were distinct from the cluster of SS2 and SS3. Interestingly, big business establishments are located in SS6 and SS7. Our team believed that these companies are able to comply with the DENR environmental regulations due to their business size and technical capacities. From the point of the local government, it would also be more tractable to perform stricter environmental monitoring with these few big companies compared to the scattered multiple home-based industries.

To investigate the sources of the individual heavy metals, we again used HCA to identify the grouping pattern of heavy metals and environmental parameters. Figure 1C shows two primary clusters of heavy metals and environmental variables consistent with Table 2. Cluster 1 consists of TOM and the heavy 
metals $\mathrm{Cr}, \mathrm{Pb}, \mathrm{Ni}$, and $\mathrm{Hg}$, associated with industrial wastes (i.e., $\mathrm{Pb}$-acid battery recycling, tannery, gold smelting, pesticide use for farming) and human and animal wastes from SS2 and SS3 and SS1, SS6 and SS7, respectively. This pattern also suggests the proximity of industrial and agricultural sources with one another. Interestingly, the Cluster 2 includes TN, TP, and $\mathrm{K}$ as these environmental variables are associated with run-offs of fertilizer use since SS4 and SS5 both are agricultural sites.

The PCA further described the identity of the sources of these polluting components. The biplot of the factor loadings of the variables and the first two dimensions identified by the principal component analysis is shown in Figure 1D. The parameters are gathered in two clusters: Cluster $1(\mathrm{Cr}, \mathrm{Hg}, \mathrm{Ni}$ and $\mathrm{Pb})$ are expected to associate with industrial effluents; Cluster 2 (K, TN, TOM and TP) suggests sources from agricultural systems and human-animal wastes. The PCA identified six dimensions that control the influx of pollutants in the Meycauayan River. Four of these dimensions have eigenvalues greater than $1 \%$, and these four explain $99.4 \%$ of the total variance. The eigenvalues, proportion of variance, factor loadings, and elemental contribution and apportionment of the dimensions are shown in Supplementary Tables 1-3.

The present-day heavy metal pollution in Meycauayan is a remnant of the several years of unregulated discharge of toxic wastewaters from several pollutive industries. $\mathrm{Hg}$ in the sediments is mainly sourced from several home-based gold smelting plants, as well as the widespread use of pesticides for farming $[11,33] . \mathrm{Pb}$ is likely attributed to $\mathrm{Pb}$-acid battery recycling industries that reportedly released their untreated wastewater to the river [13,34]. $\mathrm{Cr}$ is sourced from the tanneries in Meycauayan that also dumped their untreated wastewaters into the river [35]. Ni may have diverse industrial and commercial sources due to its chemical properties and low price. Nevertheless, Ni in Meycauayan may also be attributed to the electroplating and stainless-steel industries in Bulacan. Intuitively, K, TN, and TP are from fertilizers used in the agricultural industry, while TOM may be related to organic wastes from the numerous informal settlers who have no proper sewage treatment facilities as well as from the hog and poultry industry that have often been reported to dump wastes into the river illegally. The high positive correlation (Supplementary Table 4) and clustering of TOM and Hg (Figure 1C) are both related to household wastes from small-scale gold smelting in Meycauayan and the widespread use of pesticides for farming. Consistently, the high correlation between the individual heavy metals indicates similarities in the sources (Supplementary Table 4). We suspect that the correlation between $\mathrm{Cr}, \mathrm{Hg}$, and $\mathrm{Pb}$ as well as between $\mathrm{Cr}$ and $\mathrm{Ni}$ may relate to the stainless steel and alloy industries in the area. 

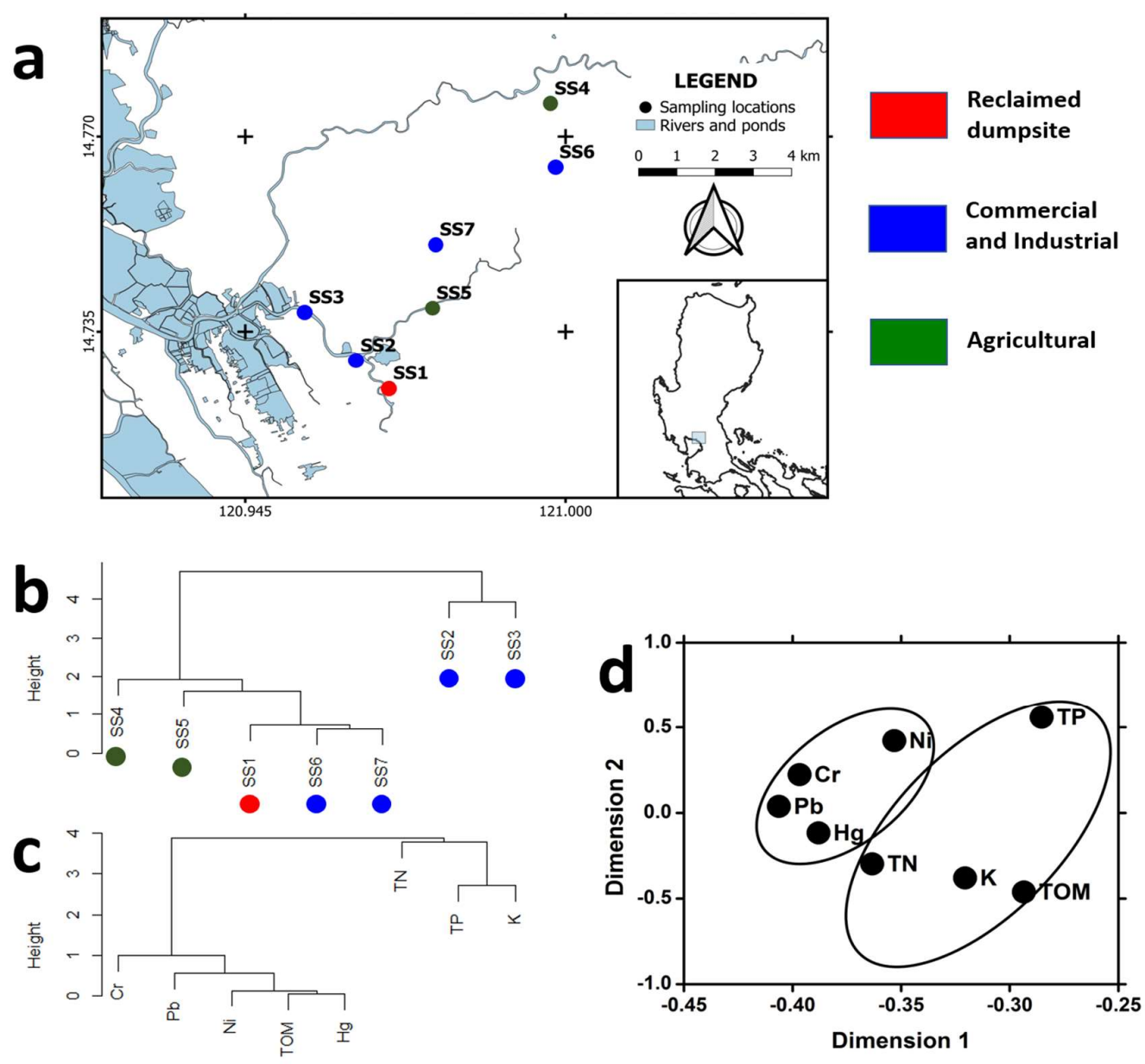

Figure 1. (a) Map of surface sediments sampling locations in Meycauayan. The sampling stations are located in the following localities: Caingin (SS1), Banga (SS2), Calvario (SS3), Camalig (SS4), Langka (SS5), Sto. Niño - Perez (SS6), and Iba (Sterling) (SS7). The (b) hierarchical dendrogram for sampling locations and (c) hierarchical dendrogram for heavy metals and environmental indicators analyzed in surface sediments of Meycauayan River sampling stations show clustering according to similarity in sources. The (d) biplot of the factor loadings of the two primary principal components or dimensions shows the clustering of heavy metals and the environmental indicators.

Note: These locations are mixed land use of mainly residential areas with other land use types such as reclaimed dumpsite (SS1), commercial and industrial (SS2, SS3, SS6, and SS7), and agricultural (SS4 and SS5).

\subsection{Ecological risks associated with heavy metal pollution in Meycauayan}

Both the SQG and PI are widely used tools in assessing heavy metal pollution in soils and sediments in freshwater ecosystems affected by the industrial discharge. For instance, these ecological risk indices were used to assess heavy metal pollution in surface sediments of Jialu River, China, and Ostrava, Czech Republic, both of which are affected by industries [24,31].

The probable effect concentration (PEC) are concentrations of heavy metals and other pollutants above which harmful effects are likely to be observed. PEC is a widely used sediment quality guideline for heavy metals and other polluting substances in sediments in freshwater ecosystems [22]. The mean probable effect concentration quotient in SS2 and SS3, as shown in Figure 2A, is greater than 0.50, which indicates that the soil and sediments are toxic and heavily polluted by heavy metals. The contributors in the individual elements are in the order of $\mathrm{Cr}(54.03 \%)>\mathrm{Pb}(18.35 \%)>\mathrm{Hg}(15.79 \%)$ $>\mathrm{Ni}(11.83 \%)$. Consequently, the mean $\mathrm{Cr}, \mathrm{Pb}, \mathrm{Ni}$, and $\mathrm{Hg}$ in the sampling locations have mean 
incidences of toxicity of $91.7 \%, 53.6 \%, 27.7 \%$, and $70.0 \%$, respectively. For the Single Pollution Index (PI), the heavy metal pollution in SS2 and SS3 reached very high pollution levels (Figure 2B), whereas SS1, SS4, SS5, SS6, and SS7 have lower levels of heavy pollution. Individually, heavy metal contributions are attributed to $\mathrm{Cr}(37.52 \%)>\mathrm{Hg}(34.91 \%)>\mathrm{Pb}(17.29 \%)>\mathrm{Ni}(10.28 \%)$.

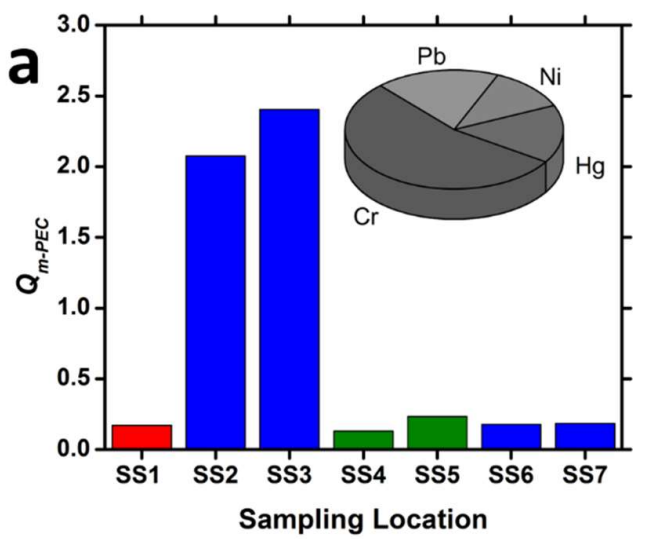

Reclaimed dumpsite

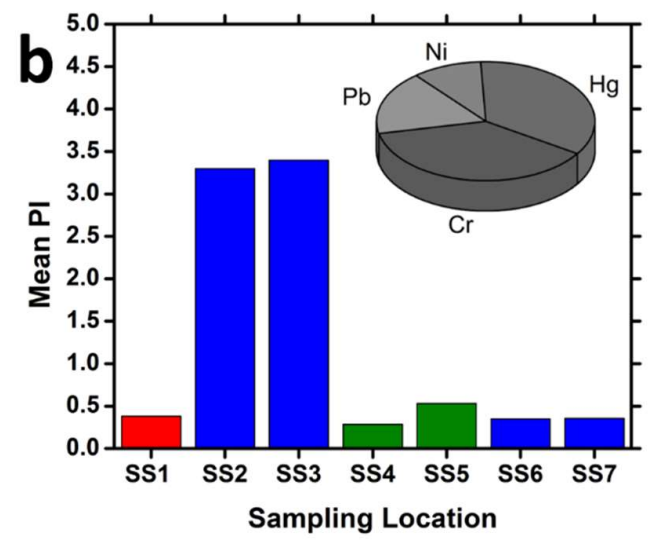

Commercial and Industrial
Agricultural

Figure 2. Risk assessments of heavy metals in surface sediments of Meycauayan using (a) Mean probable effect concentration and (b) single pollution index. The inset pie charts indicate the percent contribution of the heavy metals to the risk indices.

All in all, the risk assessments indicate that heavy metal pollution in SS2 and SS3 reached severe levels while the remaining sampling locations have lower levels of pollution. The results of the risk assessments agree with the heavy metal and spatial distribution patterns based on HCA (Figures 1BC). These results were also strongly supported from our PCA which reveals that the elemental contribution of Dimension 1 consists mainly of $\mathrm{Pb}(16.5 \%), \mathrm{Cr}(15.7 \%), \mathrm{Hg}(15.1 \%)$, and $\mathrm{Ni}(12.5$ $\%)$ that goes to SS2 (41.1\%) and SS3 (28.6\%) (Supplementary Table 2). Individually, both Cr and $\mathrm{Pb}$ consistently contributed the heaviest metal pollution in Meycauayan.

\subsection{Relationship among the heavy metals and environmental indicators}

Soil and sediment properties could be useful indicators of the extent of heavy metal pollution [36-38]. The heavy metals found in the sediments of Meycauayan River reflect the level of contamination in the sediments and undoubtedly in the river water. The chemical exchanges between these media promote interaction between the heavy metal pollutants and the water quality [15,39]. The polluted sediments and water affect the growth and survivability of the aquatic organisms. The toxic heavy metals released to the river can bioaccumulate in aquatic organisms that people consume, causing potential health issues to the people of Meycauayan and neighboring areas. Latest assessment of water quality of Meycauayan River indicates very poor quality [40].

The correlation of $\mathrm{K}$ with $\mathrm{Pb}(\mathrm{CA} \mathrm{0.741)}$ and $\mathrm{Hg}$ (CA 0.785) is attributed to NPK fertilizers and pesticides that accumulate on the soil over repeated usage [41]. It is also attributed to frequent flooding in Meycauayan that deliver and accumulate $\mathrm{Pb}$ and $\mathrm{Hg}$ in agricultural lands. Like $\mathrm{K}$, the correlation of TP with $\mathrm{Cr}$ (CA 0.835) and Ni (CA 0.944) is attributed accumulation of these heavy metals in the soil after recurring use of phosphate fertilizer [42-44]. The possibility of $\mathrm{Cr}$ and $\mathrm{Ni}$ dispersion and accumulation from recurring floods is also a feasible explanation. Nitrogen in aquatic environments is also associated with metabolism and decomposition of organisms [45]. The correlation between TN and $\mathrm{Cr}$ (CA 0.730), $\mathrm{Hg}$ (CA 0.803), and $\mathrm{Pb}$ (CA 0.791) indicate possible exposure of aquatic organisms to these heavy metals. Complexation of $\mathrm{Cr}$ and $\mathrm{Hg}$ with nitrogen species are not commonly found in the natural environment [46-49]. Although it has been found that $\mathrm{Hg}$ has higher concentration in systems 
with more nitrates and nitrites, suggesting an indirect relationship between $\mathrm{Hg}$ and nitrogen cycling [50]. $\mathrm{Pb}$ nitrate is found to bioaccumulate in some species of plants, fish, zooplankton, crayfish, and even snails [51-55]. Organic matter is also associated with decomposition of organisms, plant materials, bacteria, and algae. It is a complex soluble organic compound that plays a critical role in nutrient transport and food web flows in the aquatic environment [56,57]. The correlation between TOM and $\mathrm{Hg}$ (CA 0.705) indicates the possible complexation of $\mathrm{Hg}$ with dissolved organic matter (DOM) [58]. This complex is bioavailable to fish and bacteria [59,60]. Methylation of mercury is also possible as some inorganic $\mathrm{Hg}$ species may be more bioavailable to $\mathrm{Hg}$ methylating bacteria like sulfate and iron reducing bacteria that are found in MMORS [61-63]. Methylmercury is a very poisonous organic form of mercury that strongly bioaccumulates in aquatic food webs [64]. It is common in anoxic water and sediments [46]. Recent analysis of dissolved oxygen (DO) in Meycauayan River indicates a very anoxic condition of the river water [40].

\subsection{Policy Implications}

For developing countries, industrialization can be seen as a major initiator for urbanization. Although the merits accorded to urbanization are innumerable, the detrimental effects to the environment it brings about are devastating. Several cleanup activities have been conducted in Meycauayan River in connection to the ongoing rehabilitation of Manila Bay [67]. Current trend in government efforts is focused on eliminating solid wastes but very little has been done to address the heavy metal contamination of water and sediments and neutralize its sources. This study shows the necessity of addressing heavy metal pollution caused by industrial discharges operating in Meycauayan and neighboring municipalities. Laws like the Clean Water Act of 2004 (Republic Act No. 9275) exist to protect water bodies in the Philippines from pollution by preventing the discharge of industrial wastes to water bodies [19]. To fully rehabilitate rivers and other water bodies in the Philippines, environmental laws must be fully implemented and government policies that address the lack of standard reference values for heavy metals and other pollutants in soil and sediments ought to be enacted.

Our findings suggest that the Philippines central environmental agency, the Department of Environment and Natural Resources (DENR), adopt stricter policies to help protect the already dying environment. Presented are some key findings and suggestions that the local government of Meycauayan should take in consideration:

- Since $\mathrm{Cr}$ and $\mathrm{Pb}$ are the two major heavy metals that cause the greatest ecological risk, then the local government should focus on stricter regulation of leather tanneries and lead acidbattery recycling industries and review the zoning of these industries.

- An "environmental clean-up fund" must be available and should be part of the business taxation scheme by the local government on these pollutive industries. The money should be allocated to rehabilitate Meycauayan river as well as its soils since there are agricultural regions in the city. Flooding is a persistent problem in Meycauayan so heavy metal run-off to the farming sites is imminent.

- Meycauayan's leather processing industry started in 1903. It has been a part of the heritage and culture of the city since it was introduced by the Chinese [65]. In the past decades, the leather tanneries have been on a decline due to heavy importation of synthetic leather and the increase in prices of animal skin. Imposing heavy business taxation on the tanneries can lead to economic and job losses in the city, as well as the defacement of a city's history. Instead, there should be more rigid monitoring and support by the local government to ensure proper processing of chromium-laden wastes and avoid spill-off in the river and soils.

- The national government's legislative arm should develop laws on adopting the global move towards the phase-out of chromium (III) in leather tanning industry. This would be akin to the Minamata Convention on Mercury. The Philippines needs to set thresholds for chromium concentration in leather in the market to be regulated by the Department of Trade and Industry (DTI) and DENR. Research and advocacy on the use of abundant plant-based tannins and other alternatives should be supported by the Department of Science \& Technology.

- $\mathrm{Pb}$ acid-battery recycling plants are owned by a handful but big corporations when compared to the tanneries which are mostly made up of several small to medium-sized family businesses. 
Also, $\mathrm{Pb}$ acid-battery recycling is not part of the historical and cultural landscape of the city. Thus, the local government can and should enforce stricter regulations, taxes, and penalties on these businesses.

- With the plight of the environment and the people of Meycauayan, a "writ of kalikasan" should be lobbied by the local government. A Writ of Kalikasan is a legal remedy under Philippine law that provides protection of one's constitutional right to a healthy environment, as outlined in Section 16, Article II of the Philippine Constitution, which states that the "state shall protect and advance the right of the people to a balanced and healthful ecology in accord with the rhythm and harmony of nature." Kalikasan is a Filipino word for "nature".

- Lastly, the name of "Meycauayan" is literally translated from Spanish and Filipino as "a land full of bamboo". It was named so because during the colonization by Spain and earliest contacts in the Luzon island with Christianity, the Spanish friars named the area as Meycauayan in 1578 because of the abundance of bamboo. Unfortunately, there are no more bamboos found in Meycauayan. Since we found that bamboos, especially the Philippine giant bamboo, are excellent phytoremediators of heavy metals, we suggest including bamboo as central to the ecological rehabilitation of Meycauayan under the National Greening Program as directed by a Presidential Executive Order in 2011 [66].

\section{CONCLUSIONS}

The mean $\mathrm{Cr}, \mathrm{Pb}$, and $\mathrm{Hg}$ concentrations in Meycauayan are several times higher than the mean heavy metal concentration in sediments in rivers and lakes in the Philippines. Downstream Banga (SS2) and Calvario (SS3) have reached severe levels of heavy metal pollution due to proliferation of small-scale commercial industries like tanneries, $\mathrm{Pb}$-acid battery recycling, and gold smelting. Of the four heavy metals analyzed, $\mathrm{Cr}$ contributed most to the heavy metal pollution. There are very high mean incidences of toxicity $(>50 \%)$ associated with the heavy metals in Meycauayan that could potentially affect the well-being of the residents. The high correlation between the heavy metals and key environmental indicators is an indication of possible interaction between the heavy metals and water quality, thus exposing aquatic organisms to heavy metals. This could lead to bioaccumulation and an eventual integration to the food web.

The present heavy metal pollution in Meycauayan is a result of the past unregulated discharge of toxic wastewaters from several small-scale industries operating in it. Current focus on cleanup of the Meycauayan River only addresses the solid waste pollution in the river with little to no regard to the toxic metals present in it. Stricter enforcement of environmental policies must be observed. The lack of standard reference values for heavy metals and other contaminants in soil and sediments must also be addressed.

\section{ACKNOWLEDGMENTS}

The authors are grateful to Reynaldo San Juan, Jr., Executive Director of BANToxics for the key insights into the industrial background and toxic chemical status of Meycauayan; and to Samuel Mora of the Grand Kawayan Foundation, an environmental organization established by concerned residents of Bulacan, for approaching the university for assistance and for extending support during the sampling.

\section{CONFLICTS OF INTEREST}

The authors declare no conflicting interest.

\section{AUTHOR CONTRIBUTIONS:}

LPB, CCD, AHO, ABB, MCDG, and EAV conceived the study, wrote the paper. LPB, CCD, MCDG and EAV conceived and performed the experiments, analyzed, and interpreted the data, wrote the paper. 
LPB, RRD and CCD analyzed and interpreted the data, wrote the paper. AHO and AAB contributed materials, wrote the paper.

\section{REFERENCES}

[1] M. Ulmanu, I. Anger, E. Gament, M. Mihalache, G. Plopeanu, L. Ilie, Rapid determination of some heavy metals in soil using an x-ray fluorescence portable instrument, Res. J. Agric. Sci. 43 (2011).

[2] Z. He, J. Shentu, X. Yang, V. Baligar, T. Zhang, P. Stoffella, Heavy Metal Contamination of Soils: Sources, Indicators and Assessment, in: 2015.

[3] Y. Hu, X. Liu, J. Bai, K. Shih, E.Y. Zeng, H. Cheng, Assessing heavy metal pollution in the surface soils of a region that had undergone three decades of intense industrialization and urbanization, Env. Sci Pollut Res Int. 20 (2013) 6150-9. https://doi.org/10.1007/s11356-0131668-z.

[4] C.R. Evanko, D.A. Dzombak, Remediation of Metals-Contaminated Soils and Groundwater, Carnegie Mellon, 1997.

[5] J. Chua, J.M. Banua, I. Arcilla, A. Orbecido, M.E. de Castro, N. Ledesma, C. Deocaris, C. Madrazo, L. Belo, Phytoremediation potential and copper uptake kinetics of Philippine bamboo species in copper contaminated substrate, Heliyon. 5 (2019). https://doi.org/10.1016/j.heliyon.2019.e02440.

[6] S.H. Chen, Q.X. Zhou, T.H. Sun, P.J. Li, Rapid ecotoxicological assessment of heavy metal combined polluted soil using canonical analysis, J Env. Sci China. 15 (2003) 854-8.

[7] J.L.C. Go, C.F. Madrazo, A.H. Orbecido, M.E.G. de Castro, C.C. Deocaris, L.P. Belo, Analysis of the copper removal kinetics of the Philippine giant bamboo (Dendrocalamus asper) in hydroponics, Heliyon. 7 (2021) e06208. https://doi.org/10.1016/j.heliyon.2021.e06208.

[8] V. Grubinger, D. Ross, Interpreting the results of soil tests for heavy metals, University of Vermont, 2011.

[9] J.G. Cadondon, J.P.D. Napal, K. Abe, R. De Lara, E.A. Vallar, A.H. Orbecido, L.P. Belo, M.C.D. Galvez, Characterization of water quality and fluorescence measurements of dissolved organic matter in Cabuyao river and its tributaries using excitation-emission matrix spectroscopy, J. Phys. Conf. Ser. 1593 (2020) 012033. https://doi.org/10.1088/1742-6596/1593/1/012033.

[10] ADB, Pilot and Demonstration Activity: Philippines. Reduction of Mercury and Heavy Metals Contamination Resulting from Artisanal Gold Refining in Meycauayan, Bulacan River System., Asian Development Bank, Philippines, 2009.

[11] Blacksmith_Institute, Water Stewardship: Protecting the Marilao, Meycauayan and Obando River System, (2008). http://www.blacksmithinstitute.org/heavy-metal-pollution-in-the-mariloariver.html.

[12] L.P. Belo, A.H. Orbecido, A.B. Beltran, E.A. Vallar, M.C.D. Galvez, R.C. Eusebio, N.A. Ledesma, C.C. Deocaris, Water Quality Assessment of Meycauayan River, Bulacan, Philippines, Sylvatrop. 28 (2018).

[13] GMA_News_Online, Marilao, Meycauayan listed among world's “dirtiest," (2017). http://www.gmanetwork.com/news/news/regions/61154/marilao-meycauayan-listed-amongworld-s-dirtiest/story/.

[14] C. Alfafara, M. Maguyon, M. Laurio, V. Migo, L. Trinidad, E. Ompad, J. Sunga-Amparo, M. Mendoza, Scale-Up and Operating Factors for Electrolytic Silver Recovery from Effluents of Artisanal Used-Gold-Jewelry Smelting Plants in the Philippines, J. Health Pollut. 2 (2012) 3242.

[15] L.P. Belo, Measurement of the Sediment Oxygen Demand in Selected Stations of the Pasig River Using a Bench-Scale Benthic Respirometer, De La Salle University, 2008. https://animorepository.dlsu.edu.ph/etd_masteral/3712/.

[16] Information on Disaster Risk Reduction of the Member Countries, (n.d.). https://www.adrc.asia/nationinformation.php?NationCode=608\&Lang=en\&NationNum=14 (accessed December 31, 2019). 
[17] DENR, Water Quality Guidelines and General Effluent Standards of 2016, Visayas Avenue, Diliman, Quezon City, 2016.

[18] M.T. Malenab, E.S. Visco, D. Geges, J.S. Amparo, D. Torio, C.G. Jimena, Analysis of the integrated water resources management in a water quality management area in the Philippines: The case of Meycauayan-Marilao-Obando river system., J Env. Sci Manag. 19 (2016) 84-98.

[19] R.A. 9275, (n.d.). https://www.lawphil.net/statutes/repacts/ra2004/ra_9275_2004.html (accessed March 30, 2021).

[20] H.-F. Köhn, L.J. Hubert, Hierarchical Cluster Analysis, in: Wiley StatsRef Stat. Ref. Online, American Cancer $\quad$ Society, $\quad 2015$ : https://doi.org/10.1002/9781118445112.stat02449.pub2.

[21] I.T. Jolliffe, Principal Component Analysis, 2nd ed., Springer-Verlag, New York, 2002. https://doi.org/10.1007/b98835.

[22] D.D. MacDonald, C.G. Ingersoll, T.A. Berger, Development and Evaluation of Consensus-Based Sediment Quality Guidelines for Freshwater Ecosystems., Arch Env. Contam Toxicol. 39 (2000) $20-31$.

[23] J.B. Kowalska, R. Mazurek, M. Gąsiorek, T. Zaleski, Pollution indices as useful tools for the comprehensive evaluation of the degree of soil contamination-A review, Environ. Geochem. Health. 40 (2018) 2395-2420. https://doi.org/10.1007/s10653-018-0106-z.

[24] H.D. Weissmannova, S. Mihocova, P. Chovanec, J. Pavlovsky, Potential Ecological Risk and Human Health Risk Assessment of Heavy Metal Pollution in Industrial Affected Soils by Coal Mining and Metallurgy in Ostrava, Czech Republic., Int J Env. Res Public Health. 16 (2019) 4495.

[25] Circular on Target Values and Intervention Values for Remediation., Dutch Ministry of Housing, Spatial Planning and Environment (VROM), Netherlands, 2000.

[26] R.G. Rañola, K.S. Santiago, Assessing the Sediment Quality of Estero de Sante Bañez, a Major Tributary along Pasig River., Philipp. J. Sci. 138 (2009) 211-217.

[27] B.S. Sarinas, L.D. Gellada, E.B. Jammolangue, M.R. Teruñez, J.V. Flores, Assessment of Heavy Metals in Sediments of Iloilo Batiano River, Philippines., Int J Env. Sci Dev. 5 (2014) 543-546.

[28] S.P. Decena, M.S. Arguelles, L.L. Robel, Assessing Heavy Metal Contamination in Surface Sediments in an Urban River in the Philippines., Pol J Env. Stud. 27 (2018) 1983-1995.

[29] C.C. Cabuga, R.Y. Capangpangan, J.C. Jumawan, Levels of Heavy Metals in Fish and Sediments from Different Salinity Gradients of Lower Agusan River to Butuan Bay, Caraga, Philippines., Env. Asia. 13 (2020) 88-100.

[30] M.V. Elvira, D.V. Faustino-Eslava, M. Fukuyama, E.C. de Chavez, J.T. Padrones, Ecological Risk Assessment of Heavy Metals in the Bottom Sediments of Laguna de Bay, Philippines. Mindanao., J Sci Technol. 18 (2020) 311-335.

[31] J. Fu, C. Zhao, Y. Luo, C. Liu, G.Z. Kyzas, Y. Luo, D. Zhao, S. An, H. Zhu, Heavy metals in surface sediments of the Jialu River, China: Their relations to environmental factors., J Hazard Mater. 270 (2014) 102-109.

[32] K.P. Singh, A. Malik, S. Sinha, V.K. Singh, R.C. Murthy, Estimation of Source of Heavy Metal Contamination in Sediments of Gomti River (India) using Principal Component Analysis., Water Air Soil Pollut. 166 (2005) 321-341.

[33] L. Falkowska, A.R. Reindl, E. Szumiło, J. Kwaśniak, M. Staniszewska, M. Bełdowska, A. Lewandowska, I. Krause, Mercury and Chlorinated Pesticides on the Highest Level of the Food Web as Exemplified by Herring from the Southern Baltic and African Penguins from the Zoo, Water. Air. Soil Pollut. 224 (2013) 1549. https://doi.org/10.1007/s1 1270-013-1549-6.

[34] Z. Sun, H. Cao, X. Zhang, X. Lin, W. Zheng, G. Cao, Y. Sun, Y. Zhang, Spent lead-acid battery recycling in China - A review and sustainable analyses on mass flow of lead., Waste Manage. 64 (2017) 190-201.

[35] J. Johnson, L. Schewel, T.E. Graedel, The Contemporary Anthropogenic Chromium Cycle., Env. Sci Technol. 40 (2006) 7060-7069.

[36] S.G. Lu, S.Q. Bai, Q.F. Xue, Magnetic properties as indicators of heavy metals pollution in urban topsoils: a case study from the city of Luoyang, China, Geophys. J. Int. 171 (2007) 568-580. https://doi.org/10.1111/j.1365-246X.2007.03545.x. 
[37] R. Kızılkaya, T. Aşkın, B. Bayraklı, M. Sağlam, Microbiological characteristics of soils contaminated with heavy metals, Eur. J. Soil Biol. 40 (2004) 95-102. https://doi.org/10.1016/j.ejsobi.2004.10.002.

[38] M. Friedlová, The influence of heavy metals on soil biological and chemical properties., Soil Water Res. 5 (2010) 21-27.

[39] A. Agarwal, R.D. Singh, S.K. Mishra, P.K. Bhunya, ANN-based sediment yield river basin models for Vamsadhara (India)., Water SA. 31 (2005) 95-100.

[40] J.V.R. Pleto, V.P. Migo, M.D.M. Arboleda, Preliminary Water and Sediment Quality Assessment of the Meycauayan River Segment of the Marilao-Meycauayan-Obando River System in Bulacan, the Philippines, J. Health Pollut. 10 (2020). https://doi.org/10.5696/2156-9614-10.26.200609.

[41] J.J. Mortvedt, Heavy metal contaminants in inorganic and organic fertilizers., Fert Res. 43 (1995) $55-61$.

[42] A.S. Abdel-Haleem, A. Sroor, S.M. El-Bahi, E. Zohny, Heavy metals and rare earth elements in phosphate fertilizer components using instrumental neutron activation analysis, Appl Radiat Isot. 55 (2001) 569-73. https://doi.org/10.1016/s0969-8043(01)00098-7.

[43] M. Cheraghi, B. Lorestani, H. Merrikhpour, Investigation of the Effects of Phosphate Fertilizer Application on the Heavy Metal Content in Agricultural Soils with Different Cultivation Patterns., Biol Trace Elem Res. 145 (2011) 87-92.

[44] E.Y. Thomas, J.A. Omueti, O. Ogundayomi, The Effect of Phosphate Fertilizer on Heavy Metal in Soils and Amaranthus Caudatus., Agric Biol J N Am. 3 (2012) 145-149.

[45] K. Fog, The effect of added nitrogen on the rate of decomposition of organic matter, Biol. Rev. 63 (1988) 433-462. https://doi.org/10.1111/j.1469-185X.1988.tb00725.x.

[46] F.M.M. Morel, A.M.L. Kraepiel, M. Amyot, The chemical cycle and bioaccumulation of mercury, Annu. Rev. Ecol. Syst. 29 (1998) 543-566. https://doi.org/10.1146/annurev.ecolsys.29.1.543.

[47] J. Kotaś, Z. Stasicka, Chromium occurrence in the environment and methods of its speciation, Environ. Pollut. 107 (2000) 263-283. https://doi.org/10.1016/S0269-7491(99)00168-2.

[48] C.G. Goetz, Mercury, in: K. Kompoliti, L.V. Metman (Eds.), Encycl. Mov. Disord., Academic Press, Oxford, 2010: pp. 171-173. https://doi.org/10.1016/B978-0-12-374105-9.00043-5.

[49] E.J. Martinez-Finley, M. Aschner, Recent Advances in Mercury Research, Curr. Environ. Health Rep. 1 (2014) 163-171. https://doi.org/10.1007/s40572-014-0014-z.

[50] G.L. Lescord, T. Johnston, B.A. Branfireun, J.M. Gunn, Mercury bioaccumulation in relation to changing physicochemical and ecological factors across a large and undisturbed boreal watershed, Can. J. Fish. Aquat. Sci. 76 (2019) 2165-2175. https://doi.org/10.1139/cjfas-2018-0465.

[51] S. Jantataeme, M. Kruatrachue, S. Kaewsawangsap, Y. Chitramvong, P. Sretarugsa, E.S. Upatham, Acute toxicity and bioaccumulation of lead in the snail, Filopaludina (Siamopaludina) martensi martensi (Frauenfeld), J Sci Soc Thail. 22 (1996) 237-247.

[52] M.B. Anderson, J.E. Preslan, L. Jolibois, J.E. Bollinger, W.J. George, Bioaccumulation of lead nitrate in red swamp crayfish (Procambarus clarkii), J. Hazard. Mater. 54 (1997) 15-29. https://doi.org/10.1016/S0304-3894(96)01852-3.

[53] M.H. Jang, Y.S. Hwang, Effects of functionalized multi-walled carbon nanotubes on toxicity and bioaccumulation of lead in Daphnia magna, PLoS One. 13 (2018) e0194935. https://doi.org/10.1371/journal.pone.0194935.

[54] C. Chandrasekhar, J.G. Ray, Lead accumulation, growth responses and biochemical changes of three plant species exposed to soil amended with different concentrations of lead nitrate, Ecotoxicol Env. Saf. 171 (2019) 26-36. https://doi.org/10.1016/j.ecoenv.2018.12.058.

[55] A.-W.A. Abdel-Warith, E.-S.M.I. Younis, N.A. Al-Asgah, A.M. Rady, H.Y. Allam, Bioaccumulation of lead nitrate in tissues and its effects on hematological and biochemical parameters of Clarias gariepinus, Saudi J. Biol. Sci. 27 (2020) 840-845. https://doi.org/10.1016/j.sjbs.2020.01.015.

[56] W.F. Cross, C.V. Baxter, E.J. Rosi-Marshall, R.O. Hall Jr., T.A. Kennedy, K.C. Donner, H.A. Wellard Kelly, S.E.Z. Seegert, K.E. Behn, M.D. Yard, Food-web dynamics in a large river discontinuum, Ecol. Monogr. 83 (2013) 311-337. https://doi.org/10.1890/12-1727.1.

[57] M.M. Rojas-Downing, A.P. Nejadhashemi, T. Harrigan, S.A. Woznicki, Climate change and livestock: Impacts, adaptation, and mitigation, Clim. Risk Manag. 16 (2017) 145-163. https://doi.org/10.1016/j.crm.2017.02.001. 
[58] M.M. Reddy, G.R. Aiken, Fulvic Acid-Sulfide Ion Competition for Mercury Ion Binding in the Florida Everglades, Water Air Soil Pollut. 132 (2001) 89-104.

[59] S.A. Chiasson-Gould, J.M. Blais, A.J. Poulain, Dissolved Organic Matter Kinetically Controls Mercury Bioavailability to Bacteria, Environ. Sci. Technol. 48 (2014) 3153-3161. https://doi.org/10.1021/es4038484.

[60] J.-P. Bourdineaud, M. Gonzalez-Rey, M. Rovezzi, P. Glatzel, K.L. Nagy, A. Manceau, Divalent Mercury in Dissolved Organic Matter Is Bioavailable to Fish and Accumulates as Dithiolate and Tetrathiolate Complexes, Environ. Sci. Technol. $53 \quad$ (2019) 4880-4891. https://doi.org/10.1021/acs.est.8b06579.

[61] J.M. Benoit, C.C. Gilmour, R.P. Mason, A. Heyes, Sulfide Controls on Mercury Speciation and Bioavailability to Methylating Bacteria in Sediment Pore Waters, Environ. Sci. Technol. 33 (1999) 951-957. https://doi.org/10.1021/es9808200.

[62] I. Najera, C.-C. Lin, G.A. Kohbodi, J.A. Jay, Effect of Chemical Speciation on Toxicity of Mercury to Escherichia coli Biofilms and Planktonic Cells, Environ. Sci. Technol. 39 (2005) 3116-3120. https://doi.org/10.1021/es048549b.

[63] R.G. Abisado, J.F. Simbahan, N. Nomura, V.P. Migo, E.M. Tecson-Mendoza, L.C. Trinidad, Identification and Phylogenetic Analysis of Sulfate-reducing Bacteria Isolated from Toxic Element-contaminated Sediments in the Philippines., Phil J Sci. 144 (2015) 129-137.

[64] D.A. Matthews, D.B. Babcock, J.G. Nolan, A.R. Prestigiacomo, S.W. Effler, C.T. Driscoll, S.G. Todorova, K.M. Kuhr, Whole-lake nitrate addition for control of methylmercury in mercurycontaminated Onondaga Lake, NY, Environ. Res. 125 (2013) 52-60. https://doi.org/10.1016/j.envres.2013.03.011.

[65] brief history of tanning industry in meycauayan, (n.d.). http://www.geocities.ws/meycauayanpride/tannery/tannerybriefhistory.html (accessed April 12, 2021).

[66] Enhanced National Greening Program, (n.d.). https://www.denr.gov.ph/index.php/priorityprograms/national-greening-program (accessed April 12, 2021).

[67] M.D. Mendoza, Clean the Marilao, Meycauayan and Obando [Bulacan, Philippines] River system project [2006], in: 2008. http://agris.fao.org/agris-search/search.do?recordID=PH2007001525. 